\title{
I The East African Rift, Magma Genesis and Astheno-Lithospheric Dynamics
}

\author{
by Ali B. Kampunzu, Jean-Paul H. Caron and Ruananza T. Lubala
}

The complexity of magmas associated with intracontinental rifts is typified by the volcanic rocks of the Great Rift Valley of East Africa. The magmas evolved from continental tholeiites, rich in incompatible elements, through alkalic products to transitional magmas relatively low in incompatible elements, which characterize a proto-oceanic stage. This evolutionary sequence requires modifications to the accepted model for generating continental intraplate magmas in terms of astheno-lithospheric dynamies.

\section{Introduction}

Since the advent of plate tectonics, magmatism has moved from the category of related geological phenomena to that of a fundamental component in the evolutionary process of our planet. Indeed, our understanding of volcanism has substantially increased with the realization that $97 \%$ of active volcanoes are oceanic. Research in the ocean basins has identified many tectonic and morphological similarities between terrestrial and submarine (mid-ocean) rifts.

This work has stimulated a renewal of interest in the study of continental rifts (partly within the framework of IGCP Project 227 - Magmatism and Evolution of Extensional Regions of the African Plate. Ed.). Of special importance is the rift system of East Africa, which provides an ideal location for the study of continental intraplate volcanism. The East African Rift is far from the edges of plates, and no orogenic phenomenon has affected this part of Africa for the past $520 \mathrm{Ma}$ or so. Moreover, its northern end is a three-way junction with two oceanic ridges: the Red Sea and the Gulf of Aden.

This junction occurs in Afar (Fig. 1) which, like Iceland, is one of two regions on earth where the rocks of the present-day ocean rifts are exposed above sea level. This observation establishes unequivocally that some continental rifts were "parents" of mid-oceänic ridges (e.g. Tazieff, Varet and Barberi, 1972; Tazieff et al., 1972; Marinelli and Varet, 1973; ; Stieltjes et al., 1976).

In particular, according to Treuil and Varet (1973), there was a gradual change in magmatism, characterized by a continuous evolution from ultra-alkalic lavas in the early stages of intracontinental distension, through alkalic products (rifting) and transitional basalts (proto-oceanic stage, e.g. in Afar) to mid-ocean ridge basalts (MORBS) such as the Red Sea. This evolution is marked by a depletion in the magmas of incompatible elements, which in turn is correlated with an increase in the degree of partial melting and with the formation of successive magmas from an increasingly "depressed" mantle. For instance, for the Kivu volcanic provinces Auchapt (1985) reports a $16 \%$ partial melting for tholeiites, $5 \%$ for transitional basalts and $2.5 \%$ for basanites.
These results appear to be supported by data from geophysies and experimental petrology. In fact, Girdler and others (1969) established that the African Rift Valley overlies a layer characterized by low velocity seismic wave propagation (the Low Velocity-High Attenuation Zone, or LVHAZ) which becomes deeper from north to south in the megastructure (see also Girdler, 1983). iloreover, these data were incorporated in the experimental model for the production of magmas by diapiric upward movement of the mantle, accompanied by partial melting triggered by pressure reduction (Green and Ringwood, 1967). This model, applied to all continental rifts, is outlined in Figure 2.

This conventional scenario that assumes a gradual upward movement in the asthenosphere has recently been criticized (Lameyre et al., 1983, 1985; Giret and Lameyre, 1985).

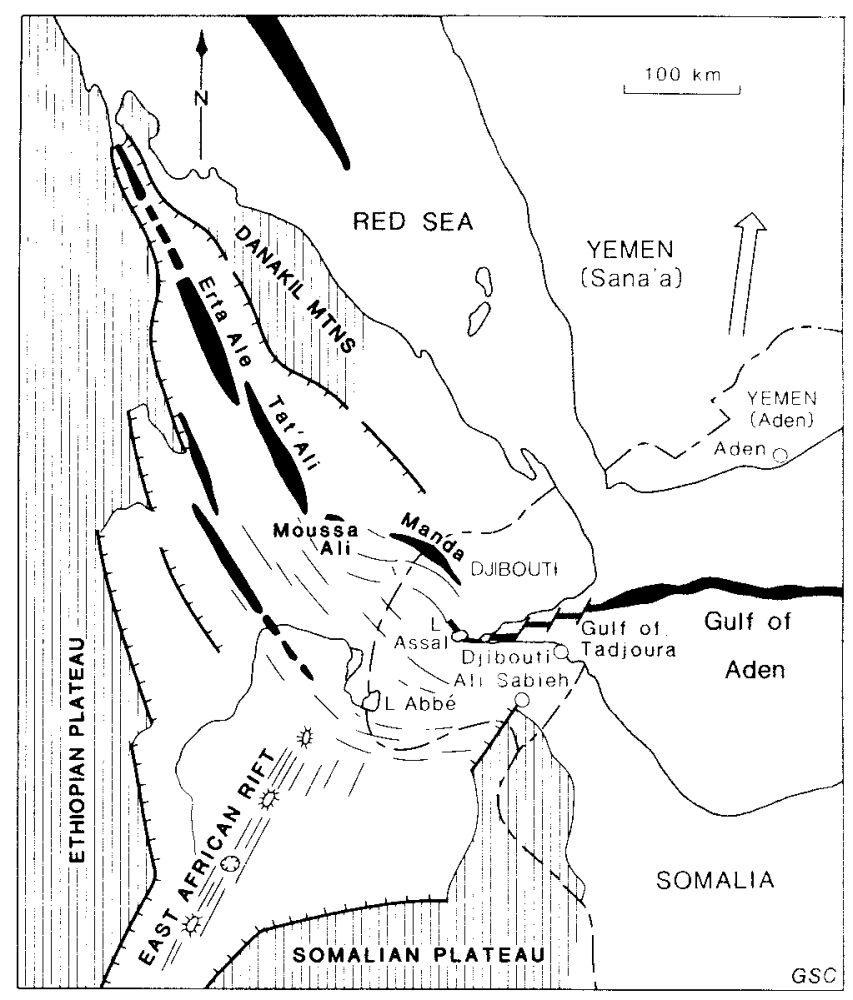

Figure 1: Tectonic diagram of Afar (after Treuil and Varet, 1973). Black - oceanic crust; vertical lines - sialic crust. 
These authors attribute the drop in pressure within the mantle to releases produced by the opening of tension cracks or "pull-aparts." Unlike the conventional model of diapirs, this hypothesis assigns an important role to translithospheric fractures and lithosere thickness. The variation in magma type is here attributed to the thinning of the lithosphere following rifting. It nould be the reverse situation of that in oceanic islands, where crust thickness increases with time.

In both interpretations, the continental tholeitic provinces are dissociated from the magmatic history of the continental rifts because they are assumed to be related only to the opening of oceanic domains. Thus, the tholeitic volcanism of the Ethiopian and Yemen plateaus has been linked solely to the opening of the Red Sea (Gass, 1972; Jones, 1976), in contradiction to field and geochronological data (Zanettin et a.., 1974). The limitations of these models can be determined by comparing tilem with the appropriate geological, chronological, petrological and geochemical data, taking into account the role of continental tholeiites in the evolution of intracontinental rifts.

Magmatic Cycles in African Intraplate Voleanies

lior the East African Rift, the nature of magmatic products in the various volcanic provinces has some obvious inconsistencies with the conventional depiction of the evolution from alkalic basalts through transitional magmas to tholeiites. The same observation also applies to other magmatic provinces of the African plate, such as the Benue Rift (Nigeria).

In eastern Zaire, three volcanic provinces (Fig. 3) have been studied in detail by seientists from the University of l.ubumbashi. In the Bukavu region, three successive volcanic cycles have been defined by Kampunzu (1981) and described in detail from the petrological viewpoint (Table 1) by many workers (Kanika et al., 1981; Lubala, 1981; Lubala et al., 1982, 1984; Caron et al., 1983; Kampunzu et al., $1983 \mathrm{a}, \mathrm{b}$ and c, 1984; and Kanika, 1984), ind by Auchapt (1985) with regard to the geochemistry of trace and minor elements.

Although it is difficult to estimate their volumetric proportions, tholeiites itppear to be the most abundant. They were also the first flows and are now purtly covered by alkalic and transitional lavas. The tholeiites have quartz or olivine in the norm and, in addition to the usual minerals in besalts, they contain subcalcic augites, pigeonites and sometimes olivines with a ferriferous tendency (up to Fo $=36$ ) in equilibrium in these magmas.

These doleritic basalts evolved under conditions of low oxygen fugacity, as in several continental tholeiitic provinces studied throughout the world (e.g.

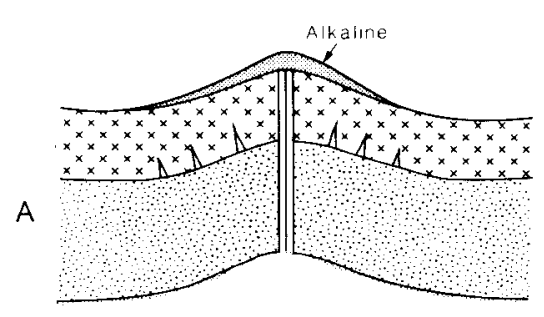

Figure 2: Relationship between asthenospheric dynamics and the production of basalts that are first ( $A$ ) alkalic ("virgin" mantle and bulging of the sialic crust), then ( $B$ ) transitional (appearance of a rift and genesis of magmas from a depleted mantle) and finalIy (C) tholeitic (oceanic stage). From Treuil and Varet (1973).

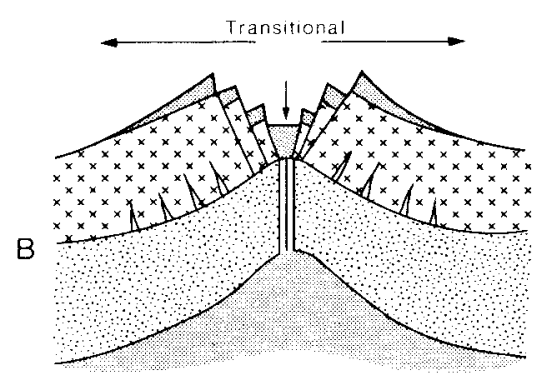

Thingmuli; Carmichael, 1967). Although the early position of this volcanism in the volcanic sequence of Bukavu is unanimously accepted, currently available radiometric data (Guibert, 1978; Bellon and Pouclet, 1980; Kampunzu, 1981; Baubron, 1983; Pasteels et al., 1985) do not agree. However, the likeliest ages are between 18 and 7 Ma.

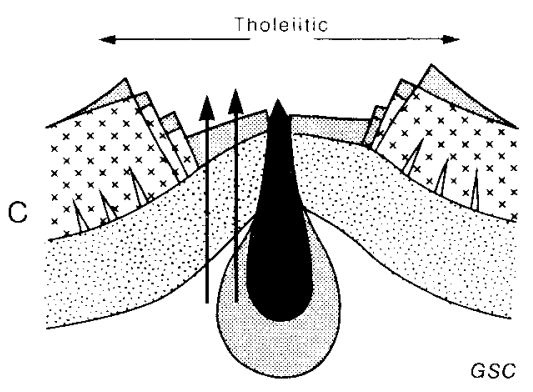

The last effusions of this tholeiitic cycle were synchronous with the first outflows of alkalic lavas constituting the second volcanic cycle, which began around 8 Ma ago (Bellon and Pouclet, 1980; Lubala, 1981; Pasteels et al., 1985). This cycle is subdivided into two episodes, Neogene (8-3.6 Ma) and Early Pleistocene (1.9-1.6 Ma). The alkalic volcanism consists of a normal sodic sequence, with ankaratrites, basanites, hawaiites, mugearites, benmoreites, trachytes and phonolites. The $\mathrm{co}^{-}$ existence of undersaturated and oversaturated types is normal in such a setting.

The last voleanic outflows in the Bukavu region were transitional basalts or olivine tholeiites of the third cycle. Some were erupted from hyaloclastic cones built after formation of Lake Kivu during the Late Pleistocene (Kampunzu et al., 1984).
TABLE 1

Mineralogy and ages of rocks of the three volcanic cycles in the Bukavu region. Geochronological data in part from Bellon and Pouclet (1980), Pasteels et al. (1985), and Baubron (1983).
Rock type

III Cycle Transitional basalts and

01 - tholeiites

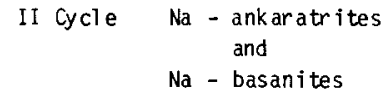

I Cycle Qz or 01 - tholeites
Mineralogy

Mineralogy
P1 (An 66-39) + 01 (Fo 88-
$68)+\mathrm{Cpx}(\mathrm{Ca} 48-37, \mathrm{Mg}$
$41-35) \pm T i-M t($ Usp: 64-58)
$\pm \mathrm{I}$ m (Hem: 14-12)
$\pm \mathrm{Cr}$-Sp (Cr/Cr+Al: 42-33)
$+\mathrm{glass}$

P1 (up to An 73 Ab 26)

+01 (Fo 86-59) + Cpx

(Ca 51-41, Mg 38-41)

$+\mathrm{Fe}-\mathrm{Ti}$ oxides + glass

P1 (An 68-35) + Cpx

(Ca 47, Mg 42-63) + 01

$($ Fo 79-36) $+17 \mathrm{~m}$

(Hem: $0-10)+\mathrm{Ti}-\mathrm{Mt}$

(Usp: 43-71) \pm glass. 


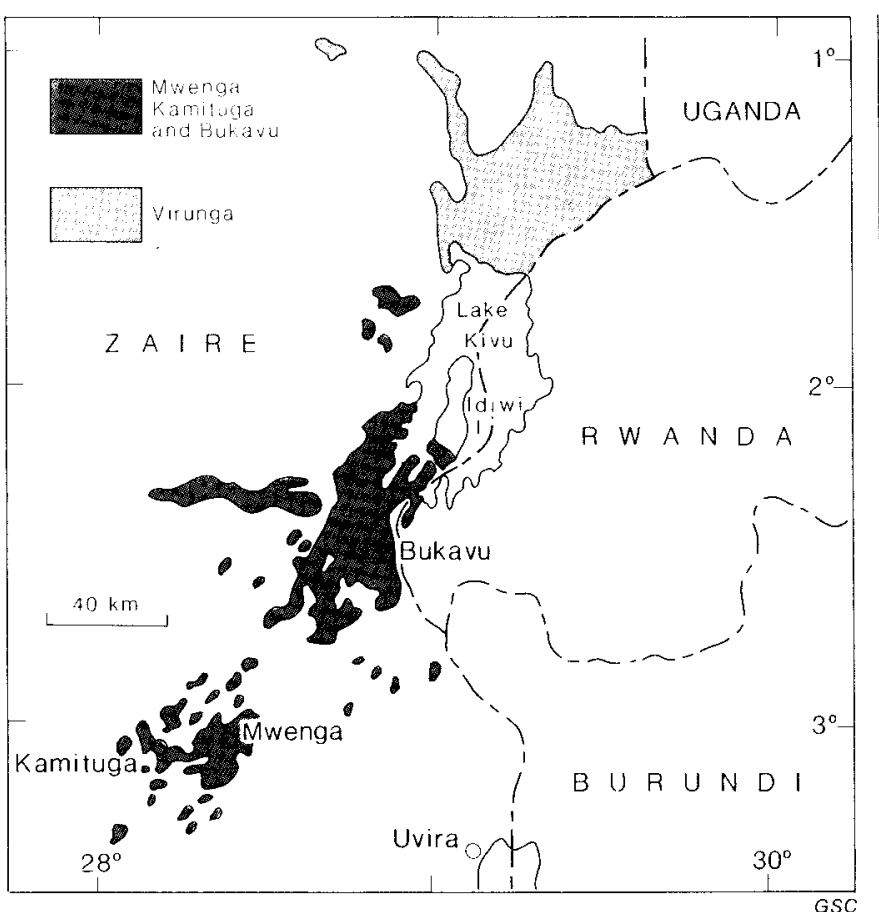

Figure 3: Map showing the distribution of the volcanic provinces of Mwenga-Kamituga, Bukavu, and Virunga .

In the Mwenga-Kamituga region (Fig. 3), the sequence of magmatic cycles exactly matches that found in Bukavu, with tholeiites at the base, alkalic lavas (with relatively unevolved end products, up to the hawaiites) and finally, a recurrence of saturated basalts at the top (Kanika, 1984). The difference lies in the age of the initial volcanism, which began later than $5 \mathrm{Ma}$ ago.

In both Bukavu and Mwenga-Kamituga volcanic provinces, the geochemical properties of the continental tholeiites making up the first volcanic cycle are comparable and similar to the continental tholeiites associated with the A tlantic opening (Fig. 4 and Table 2).

In the volcanic district of the Virunga Mountains (Fig. 3), the first basaltic outflows are also saturated (olivine tholeiites), though of relitively minor extent (Kampunzu et al., 1983b). The same applies to the lavas constituting the alkalic second cycle, which form a sodic sequence evolving from ankaratrites to benmoreites (Kampunzu et al., 1982). The basic difference between this volcanic province and those mentioned earlier is the lack of recurring saturated basalts.

The Pliocene-Quaternary lavas of the Virunga chain (Fig. 5) are potassic to highly potassic. They are associated with eight main volcanoes, including the famous Nyiragongo and Nyamulagira, (Fig. 6), the most active "continental" volcano of the African Rift Valley (Kampunzu et al., 1985). These volcanoes are aligned along a fracture zone transverse to the rift axis, which is interpreted as a newly formed transform fault in a continental domain (Vellutini et al., 1982;). A similar continental transform fault also appears to characterize the ultra-alkalic, late Tertiary to Quaternary province of northern Tanzania, which is strongly sodic and contains carbonatites. Work under way should enable us to determine whether this relationship linking ultra-alkalic magmatism to transform faults holds true for other continental plates.

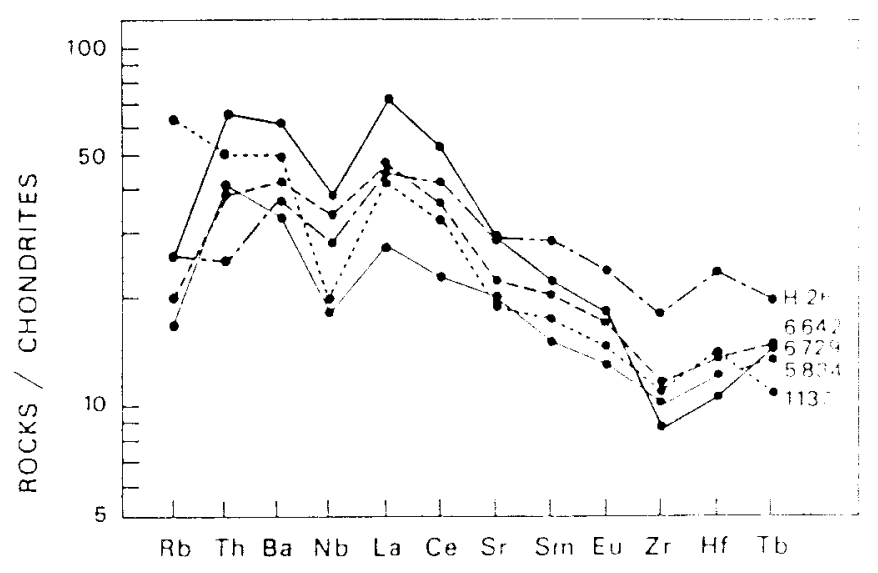

Figure 4: Chondrite-standardized multi-element spectra of continental tholeiites from the western branch of the African Rift Valley (6729 - Kamituga; 6642 - southern Idjwi Island in the Bukavu region) and from the Atlantic opening (1137 - Morocco; 5834 - Nova Scotia). Note the similarities with the basalts of the oceanic islards (H26 - Hawaii tholeite). From Auchapt (1985).

TABLE 2

Average compositions of selected first volcanic cycle tholeites in zaire (new data), and representative analyses of Moroccan tholeites associated with opening of the Atlantic Ocean (from Bertrand it al., 1982). A - 3 samples from the Mwenga-Kamituga area; B - 8 samples from Bukavu district; C - from the Anti-Atlas; D - from the High Atlas. Oxides in 8 , other elements in ppm.

\begin{tabular}{|c|c|c|c|c|c|c|}
\hline & & A & & $\mathrm{B}$ & C & $\mathrm{E}$ \\
\hline $\mathrm{SiO}_{2}$ & 51.00 & \pm 2.00 & 51.20 & \pm 0.70 & 50.97 & 52.96 \\
\hline $\mathrm{Al}_{2} \mathrm{O}_{3}$ & 15.06 & \pm 0.70 & 15.10 & \pm 0.50 & 14.40 & 13.16 \\
\hline $\mathrm{Fe}_{2} \mathrm{O}_{3} \mathrm{t}$ & 10.50 & \pm 1.00 & 11.60 & \pm 0.30 & 10.22 & 10.80 \\
\hline $\mathrm{MnO}$ & 0.17 & \pm 0.01 & 0.18 & \pm 0.03 & 0.15 & 0.19 \\
\hline MgO & 7.02 & \pm 0.70 & 6.10 & \pm 0.50 & 7.80 & 7.66 \\
\hline $\mathrm{CaO}$ & 9.84 & \pm 0.20 & 9.40 & \pm 0.90 & 11.62 & 9.07 \\
\hline $\mathrm{Na}_{2} \mathrm{O}$ & 2.63 & \pm 0.10 & 2.80 & \pm 0.20 & 1.91 & 2.53 \\
\hline $\mathrm{K}_{2} \mathrm{O}$ & 0.33 & \pm 0.04 & 0.33 & \pm 0.05 & 0.33 & 0.42 \\
\hline $\mathrm{TiO}_{2}$ & 1.39 & \pm 0.02 & 1.66 & \pm 0.10 & 0.97 & 1.34 \\
\hline $\mathrm{P}_{2} \mathrm{O}_{5}$ & 0.32 & \pm 0.02 & 0.28 & \pm 0.06 & 0.14 & 0.23 \\
\hline $\mathrm{Li}$ & 3.30 & \pm 0.60 & 5.40 & \pm 1.50 & 9 & 11 \\
\hline $\mathrm{Rb}$ & 7.30 & \pm 2.00 & 9 & \pm 3 & 12 & 42 \\
\hline $\mathrm{Sr}$ & 298 & \pm 10 & 272 & \pm 46 & 167 & 200 \\
\hline $\mathrm{Ba}$ & 234 & \pm 12 & 249 & \pm 130 & 92 & 208 \\
\hline V & 179 & \pm 1 & 206 & \pm 17 & 285 & 239 \\
\hline $\mathrm{Cr}$ & 197 & \pm 36 & 232 & \pm 20 & 201 & 206 \\
\hline $\mathrm{Co}$ & 45 & \pm 7 & 53 & \pm 14 & 45 & 46 \\
\hline $\mathrm{Ni}$ & 133 & \pm 44 & 138 & \pm 32 & 92 & 85 \\
\hline $\mathrm{Cu}$ & 71 & \pm 5 & 70 & \pm 20 & 240 & 132 \\
\hline $\mathrm{Zn}$ & 90 & \pm 5 & 113 & \pm 15 & 124 & 223 \\
\hline La & 23.30 & \pm 0.50 & 27 & \pm 15 & 6.84 & 19.20 \\
\hline $\mathrm{Ce}$ & 43.50 & \pm 2.00 & 49 & \pm 26 & 14.20 & 39.40 \\
\hline $\mathrm{Sm}$ & 4.18 & \pm 0.20 & 5.45 & \pm 1.9 & 2.52 & 4.73 \\
\hline Eu & 1.44 & \pm 0.10 & 1.83 & \pm 0.6 & 0.91 & 1.39 \\
\hline $\mathrm{Tb}$ & 0.69 & \pm 0.05 & 0.98 & \pm 0.3 & 0.48 & 0.81 \\
\hline $\mathrm{Yb}$ & 1.86 & \pm 0.02 & 2.70 & \pm 0.8 & 1.76 & 2.40 \\
\hline Lu & 0.30 & \pm 0.01 & 0.43 & \pm 0.1 & 0.30 & 0.40 \\
\hline Th & 3.20 & \pm 0.20 & 3.50 & \pm 2.0 & 1.20 & 4.30 \\
\hline HE & 2.00 & \pm 0.10 & 3.30 & \pm 1.0 & 1.90 & 4.10 \\
\hline $\mathrm{Sc}$ & 24 & \pm 1 & 25 & \pm 2 & 36 & 32 \\
\hline$Y$ & 26 & \pm 2 & 35 & \pm 8 & 24 & 33 \\
\hline $\mathrm{Zr}$ & 80 & \pm 3 & 108 & \pm 20 & 71 & 155 \\
\hline $\mathrm{Nb}$ & 21 & \pm 1 & 24 & \pm 7 & 6.60 & 16.10 \\
\hline
\end{tabular}


In southwestern Tanzania, the western branch of the Rift Valley contains alkalic lavas (Harkin, 1960). According to modern classifications, such as those using the $\mathrm{Na}_{2} \mathrm{O}-\mathrm{K}_{2} \mathrm{O}$ ratio, these lavas could be attibuted to a sodic alkalic series evolving from ankaratrites to phonolites and trachytes, as in the Kivu area. The lack of transitional basalts overlying these alkalic lavas distinguishes this immature rift region from the other voleanic provinees of the African Rift Valley. On the other hand, our preliminary data on the petrological characteristics of the early basalts of this region indicate that these are also tholeiitic in nature.

In the eastern branch of the Rift Valley, which has been studied for a very long time, a link between the degree of rifting and the eruption of continental tholeiites, found particularly in Kenya, has only recently begun to be established (Bellieni et al., 1981; Watkins, 1981). Here, tholeiitic transitional basalts were emplaced between approximately 33 and $30 \mathrm{Ma}$ ago (Zanettin et al., 1983), and the last outflows of this tholeiitic eycle were nearly synchronous with alkalic lavas (second cycle). The transitional Lothidok basalts have been dated at $15 \mathrm{Ma}$ old, but currently available data do not allow us to determine whether they represent the end of the initial tholeiitic magmatism or the beginning of the transitional cycle marking an evolved stage of rifting.

The transitional stage (third cycle) is, however, represented by the Pliocene-Quaternary transitional magmas deseribed in both Kenya and Ethiopia (e.g. Zanettin et al., 1974; Baker et al., 1978; Lippard and Truckle, 1978; Piccirillo et al., 1979; Barberi and Santacroce, 1980). These magmas always appear after the first cycle tholeiites and the second cycle alkalics. They are early in the evolution of continental rifts, because in Bukavu voleanic province they are directly above a zone of weak crustal extension and upward movement of the asthenosphere.

In Afar, where the conventional process of magmatic evolution from alkalic compositions through transitional to oceanic tholeiites was established (Treuil and Varet, 1973), earlier workers had totally dissociated the volcanism of the Afar depression (see cover photo) from the older basaltic series that constitutes the Ethiopian Plateau and that extends into Ethiopia and Yemen. These Ethiopian basalts are essentially continental tholeiites (Jones, 1976; Schubert, 1975; Mohr, 1983), of the same type and significance as their equivalents in the intracontinental volcanic provinces of the Rift Valley. Thus the initial magmatism of the

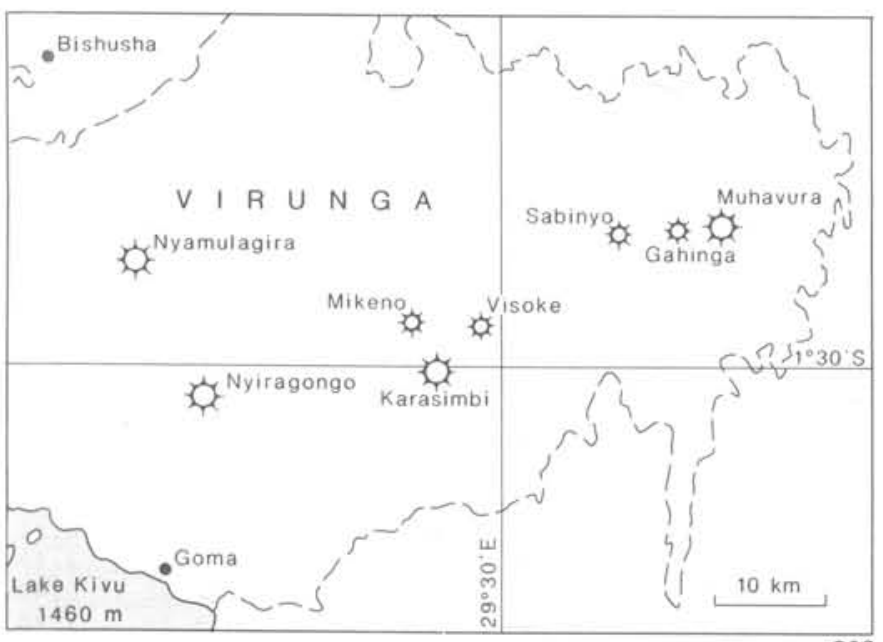

GSC

Figure 5: Distribution of Pliocene-Quaternary lavas of the Virungas (within dashed line) and location of various major volcanoes. See also cover photo. various volcanic provinces of the African Rift is elearly tholeiitic in nature, despite other views often expressed in the literature (e.g. references in Giret and Lameyre, 1985).

The same applies to the Benue Rift of West Africa, where basalts show a chemical evolution from Jurassic olivine tholeiites to Cretaceous alkalic compositions (Popoff et al., 1982). Certain magmatic provinces of the Cameroon Line have been relatively well studied, and their alkaline nature has been emphasized; they are interpreted in terms of the classic model of intracontinental rifting. In fact, in the plutonic-voleanic complex of Golda-Zuelva, at $66 \mathrm{Ma}$ the oldest gabbroic intrusion of the Cameroon Line (Jacquemin et al., 1982) contains or thopyroxene in equilibrium and early plagioclase (Jacquemin, 1981), a combination difficult to conceive of in basic materials of an alkalic nature. The high content and fractionation of LREEs in these products, described by Jacquemin (1981), is not strong enough evidence of an alkalic base, because this is standard in continental tholeiites (Dupuy and Dostal, 1984).

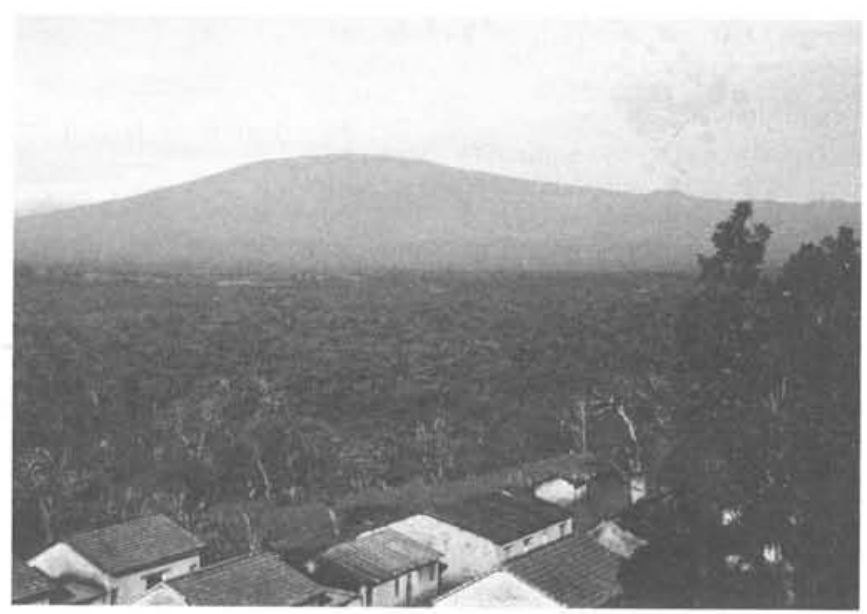

Figure 6: Nyamulagira, the only shield volcano in the Virunga chain.

Similar observations ean be made regarding several African magmatic provinces said to be alkalic (such as the Iskou massif of the Air in Niger, described by Leger, 1985). For example, among the marine volcanics of the Cameroon Line, the first flows of Principe Island $(\approx 31$ to $23 \mathrm{Ma}$ old; Dunlop and Fitton, 1981; Dunlop, 1983) are tholeiitic. They are overlain by subaerial voleanics consisting of sodic alkalic lavas with a level of undersaturation that decreases from the "old" basalts and hawaiites $(\approx 23$ to $19 \mathrm{Ma})$ to recent basanites $(\approx 5$ to $3 \mathrm{Ma}$, Dunlop, 1983).

The volcanic succession we are proposing for these magmatic provinces of Africa is consistent with that marking the start of the Atlantic opening (e.g. Bertrand and Prioton, 1975; Bertrand and Coffrant, 1977; Bertrand et al., 1982; Bellieni et al., 1984). Indeed, though earlier work suggested that the continental rifts are the beginnings of oceanic rifts (e.g. Girdler et al., 1969; Gass, 1972; Burke and Whiteman, 1973), the sequence of magmatic cycles proposed earlier in the African Rift Valley is not consistent with this interpretation.

Contrary to what is conventionally accepted (see syntheses of Lameyre et al., 1983 and 1985; Giret and Lameyre, 1985), the magmatic succession we describe indicates that there was no reverse evolution of the magmatic sequences in the continental rifts and oceanic islands. Indeed, everything takes place as if the mechanisms were the same at the outset. The only differences occur when the development of the rifting process on the continents introduces a new 
parameter into the evolution of the magmas and leads to the recurrence of saturated basic magmas. In short, the genesis of intraplate magmas should be attributed to the same mechanisms, regardless of whether the products are continental or oceanic. This conclusion has ramifications for models of magma genesis as it relates to the dynamies of the asthenosphere and lithosphere.

\section{Mantle Magmas and Astheno-Lithospheric Dynamies}

There are conflicts between the distribution in space and time of magmatic activity and the model of gradual upward movement of asthenospheric diapirs. According to the second model, alkalic liquids are produced first at great depth (in the continental rifts), and are succeeded by relatively shallow transitional magmas (evolved continental rifts and proto-oceanic rifts of the Afar type), and finally by oceanic (NORB) tholeiitic magmas. Indeed, the tholeiitic nature of the first basalts extruded in the African rifts implies melting under low pressures that correspond in the diapiric model to shallow depths. On the other hand, the subsequent alkalic lavas would result from partial melting at greater depth, indicating a deepening of the level of magma genesis with time, contrary to the diapiric hypothesis.

It is possible, of course, that the pressure drop does not reflect a rise in the LVHAZ, but rather a release caused by lithospheric fracturing (Lameyre et al,, 1983 and 1985). This, however, cannot be verified using available geophysical data on present rifts, since it assumes that the geometry of the asthenospheric "tumour," and the associated crustal bulging, are the result of a volume increase related to melting. According to this model, the inverted sequence of tholeiitic and alkalic intraplate magmas (oceanic and continental) is explained by the variation with time of lithosphere thickness. In the oceanic islands, which are being built up gradually by thickening the lithosphere beneath them, the magmas evolve from tholeiitic to alkalic.

According to Lameyre and others, the progressive lithospheric thinning that characterizes the rifting process will be marked by a sequence the reverse of that observed in oceanic islands, i.e. from alkaline to transitional basalts. Such an explanation may apply to the passage from alkaline to transitional volcanics, but it cannot explain the passage from tholeiites to alkaline compositions observed in the African Rift.

The advantage of this model lies in the fact that it attributes an important role to lithospheric dynamies in the formation of intraplate volcanic provinces. In fact, certain parts of the African Rift Valley (such as the Tanganyika and Mobutu Lakes regions in Central Africa), are characterized by similar gravimetric anomalies, although not everywhere are volcanic provinces found directly above them. The volcanic regions are generally located at the junction of two or more major fracture zones.

Another aspect is the link that seems to exist between peralkaline magmatism and continental transverse fractures (Vellutini et al., 1982). However, models that take into account only lithospheric dynamies are, like the diapiric hypothesis, unsatisfactory. Indeed, highly potassic volcanic provinces such as the Toro-Ankole in Uganda, are related to active faults that are interpreted as trans-lithospheric fractures that triggered melting by lowering the pressure. Such fractures should at the same time have caused a release in pressure in the upper zones of the mantle. The lack of saturated and moderately alkalic basalts in this region is not entirely consistent with this hypothesis.

\section{A New Model}

To reconcile all available data, we propose a model involving the combined dynamies of the asthenosphere and lithosphere, in which the evolution of the rifting process is correlated to the nature of the magmas emplaced. This involves consideration of the upward movement of the asthenospheric "cushion" whose existence beneath the continental rifts has been established by geophysical data. We feel that, at the start of a distension event, there is an almost instantaneous (geologically speaking) asthenospheric rise throughout the whole solid mantle. This upward movement is blocked at the base of the crust, at depths that obviously vary with crustal thickness in each region considered.

Depending on this depth, the first magmas produced at the top of the rising asthenosphere would be more or less saturated basalts (e.g Kivu) and even, exceptionally, alkalic magmas, such as at Toro-Ankole. The whole of the rising asthenosphere is in disequilibrium because of the fall of pressure, and partial melting takes place simultaneously at all levels in the ascending diapir. The liquids produced are tholeiites at shallow levels, transitional at intermediate levels and alkaline at greater depths. The time of arrival of these magmas at the surface is determined by their level of formation, with tholeiites and transitional types at the base (first eycle) followed by alkaline basalts of the second cycle.

This mechanism explains the decrease in magma saturation with time observed in the oceanic islands and in the first evolutionary stages of the continental rifts. It also allows for the overlap in age between alkalic and tholeiitic magmas in different volcanic provinces of the East African Rift Valley (Kampunzu et al., 1985). It could even explain the simultaneous outflowing of LIL-rich and LIL-poor basalts in the oceanic domain (e.g Iceland, Sigvaldason et al., 1974 and 1976).

The recurrence of saturated basalts of the third cycle, characteristic of several volcanic provinces in the Rift Valley but not of the oceanic islands, seems to indicate a difference in the energies of the diapiric systems of these two different settings. Indeed, this recurrence seems to characterize continental rifts with a potential of becoming oceanic, and it reflects a high-energy diapir. This situation occurs only where there is asthenospheric rise of large proportions with regard to mass, speed and, probably, temperature.

\section{A Final Comment}

It should be pointed out that this improvement in our understanding of the Rift Valley volcanism has been made possible only by the use of detailed mapping and structural analysis. Unfortunately, this approach is being abandoned more and more by geologists, especially as field work conditions in Africa are not as comfortable as in the developed countries. On the other hand, field work cannot be fully utilized in preparing models unless it is backed up by exacting laboratory analysis.

These two aspects eould form a good basis for North-South cooperation, but African researchers usually do not have the funds to finance research work, especially when such work does not have short-term economic applications. International agencies and the wealthier countries should thus encourage the geological sciences by granting research funds to experienced African teams who are able to collaborate on an equal footing with their colleagues from the developed countries.

Acknowledgements: The helpful advice of Prof. L. Aguirre and C. Coulon (Marseille) and of an anonymous reviewer is greatly appreciated. 
Prof. A. B. Kampunzu is Director of the Petrology Laboratory at the University of Lubumbashi in Zaire, based temporarily at the University of Aix-Marseille III (Lab. de Pétrologie, Saint-Jérôme, 13397 Marseille 13, France). He is currently Vice-President of the Geological Society of Africa, co-leader of IGCP Project 227, and Chairman of the Consultative Committee for the Uneseo program "Geology for Development."

Dr. J.-P. H. Caron is presently on leave from the University of Aix-Marseille and teaching geology at the University of Lubumbashi (B.P. 756, Lubumbashi, Zaire). He has worked on the Triassic of Provence and now studies the structural geology of the Great Rift Valley and its Precambrian basement. (Photo not available)

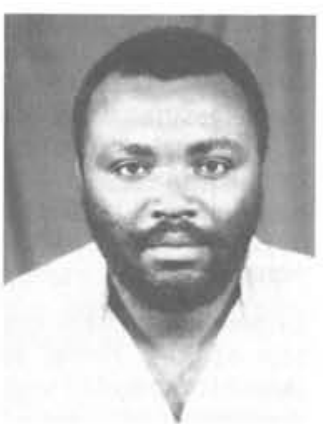

Prof. R.T. Lubala is also based in the Department of Geology at Lubumbashi, where he is Director of the Laboratory for African Geology. He is co-leader of IGCP Project 227 and GSA representative in Zaire. His research is also focussed on the magmatic and structural evolution of the Rift system and the Precambrian orogens of central Africa.

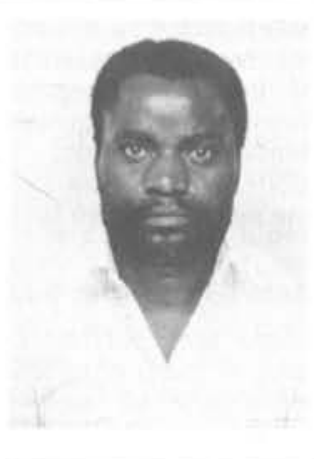

Reterences

Auchapt, A., 1985. Les éléments traces dans les basaltes des rifts Continentaux: exemple de lí provinee du Sud kivu (Zaire) dans le rift Est Afrieain. Thesse 3ème eyele, Univer
Languedoc-Montpellier, France, 81p.

Bakes, B.H., Crossley, R. and Goles, G.G., 1978. Tectonic and
magmatic evolution of the southern part of the Kenya rift valley, In: E.R. Neumann and I.B. Ramereng (eds, ), Petrology and geochemistry of continental rifts, Proceedings of the NATO Advanced Study Institute, Paleorift systems with emphusis on the Pernian Oslo Bift,

Barberi, F. and Santacroce, $\mathbb{R}_{\text {., }} 1380$. The Afar stratold series and the magrmatic evolution of east Afriean rift system. Builict

Baubron, J.C., 1983. Reconnaissance géothermique de la République Bellieni, G. Visentin, E.. Zanettin, B., Piceirillo, E.M., Radicati, D.1., Brozolo, F. and Rita, F.. 1981. Oligocene transitional tholeititic Coeval Ethiopian voleanism, Bulletin Volcanologique, v. 44 , no. 3.
p. $411-427$.

Bellieni, G., Brotzu, P., Comin-Chimramonti, P., Ernesto, M., Melfi,

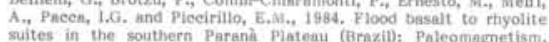
petrogenesis nnd geodynamie implieations. Journal of Petrology,

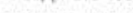

Bellon, H. and Pouclet, A., 1980. Datations $\mathrm{K}$-Ar de quelques laves du Rift-Ouest de l'Afrique Centrale; impliceations sur lévolution
magmatique et strueturale. Geologische Runisehinu, v, 69, no. I,
p. $49-62$.

Bertrand, H. and Cotfrant, D., 1977. Geochemistry of tholeittes from North-East American margin: correlation with Moroceo: a
statistical approach. Contributions to Mineralogy and Petrology,
v, 63 , p. 65-74.

Bertrand, H., Lostal, J. and Dupuy, C., 1982. Ceochemistry of Enriy Mesozoic tholeites from Moroce
ters, v. 58, no. 2, p. 225-239.

Bertrand, H. and Prioton, J.M., 1975. Les dalérites maroenines et louverture de 1Atlantiquet étude pétrologique et géochimique.

Burke, K. and Whiteman, A.J.. 1973. Uplift, rifting and the break-up

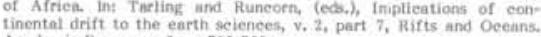
tinental drift to the earth sciences
Academie Press, no. 2, p. 735-755.

Carmichael, 1.S.E., 1967. The mineralogy of the Thingmuli, a na. 11-12, p. 1815-1841.

Caron, J-P.H., Kampunzu, A.H., Kanika, M. Makutu, M.N. and
Vellutini, P-J., 1983, Les éléments en traces dans les laves de la Haute-Ruzizi (Rift Valley du Kivu, Zaire). Comptes-Rendus des Séences de PAcadérnie des Sciences, Série 2, v. 296, no. 4, Dunlop, H.M., 1983. Strontiun isotope geochemistry and potussium
angon studies on voleanie rocks from the Cameroun-Line, West argon studies on voleanic rocks from the Camer
Afriea. Ph. D. Thesis, University of Edinburgh, 347 p.

Dunlop, H.M. and Fitton, J.G., 1981. A K-Ar and Sr-isotopie study of
the voleanie rocks of the istand of Principe, West Africa: Evicenee the voleanic rocks of the island of Prineipe, West Africa; Evidenee for mantle heterogeneity berieath the gulf of Guinea.
to Minerulogy and Petrology, v, 71, no. 2, p. 125-131.

Dupuy, C. and Dostal, J., 1984. Geoebemiatry of some continental p. $6 \mathrm{l}-59$.

Gass, 1.6.. 1972. The role of lithothermal systems in magauatic and Girdler, R.W., 1983. Processes of planetary rifting as seen in the

Gircler, R.W., F nirhead, J.D., Searie, R.C. and Sowerbutts, w.T.C., p. $1178-1182$.

Giret, A. and Lameyre, J., 1985. Inverted alkaline-tholeitic senental rifts and ocenthic islands, Journal of Atrican Entth Sciences nental rifts and ceentic
$v .3$, no. $1 / 2$, p. $281-268$.

Green, D.H. and Ringwood, A.E., 1967. The genesis of basaltic magmas, Contributions Mineralegy and Petroloky, v. 5, no. 2,
p. 103-190,

Gubbert, P., 1978, Contribution à Yétude du voleanisme de la chaine des Virunga (République di
Université de Geneve, 15ip.
Harkin, D.A., 1960. The Rungwe voleanics at the northern end of Thake Nyass, Memoir Geologiesil Survey of Tanganyika, II, 172p. Jaequemin, H., 1981 . Contribution de l'étude géochimique des Exemple des massifs de Mtroutou et de Golda Zuelva (Nord Cameroun). Thèse łène Cyele, Université Naney 1, Hrance, 253p. Jaequemin, J., Sheppard, S.M.F. and VidmL, P., 1982. Botopic geoehemistry $(0$, , Sr, Pb) of the Golda Zuelva and Miboutou anorogenic complexes, North Cameroun; Mantle origin with evidence for erustal
eantanination. Earth and Planetary Seience Letters, v. 61, no. 1, contarminat
p. $97-111$.

Jones, P.W. 1976. Le magmatisme au stade initial de la fragnientation des plaques arutique, nubienne et somalienne. Bulteri
Géologique de France, Série $7, v, 17$, no. 4, p. 829-830.

Kampunzu, A.ß., 1981. Le magmatisme du mnssif du Katiuzi (Kivu, Zaire): Structure, petrologie, significetion et implication géodyn. Kampunzu, A.H., Caron, J-P.H., Kankika, M. and Lubata, K.T., 1985 .
Evolution du rifting intracontinental et magmas tholéitique, tranEvolution du rifting intracontinental et magmas tholeutitique, tran-
sitioninel et alcalin associést cas du volcanisme phanérozoique du rift
Africain, 13th Collociun African Geology, St, Andrews, Scothand Abstracts in Oecasional Publication 1985/3, CIPEG-Paris, D. 174-175,

Kampunzu, A.B., Caron, J-P.H., Vellutini, P-J. and Bizimana, B.L.. 1983a. Sur in hature et in signifieation des laves basiques du Sud-Ouest de Pile d'lojwi dans le tue Kivu au Znire (Rift Afrienin).
comptes Rendus des Sénnces de l'Achicémie des Sciences, Série 2, Comptes Rendus des Séminces
v. 296, no. 12, p. $204-912$.

Kanpunza, A.B., Kanika, M.. Caron, J-P.H.. Lubails, R.T. and Vellutini, P-J., 1984. Les basaltes transitionnels dans l'évolution des

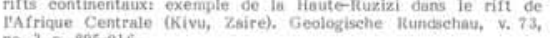
no. 3, p. $895-916$.

Kampunzu, A.B., Lubais, R.T., Caron, LP.H. and Vellutini, P-3.,

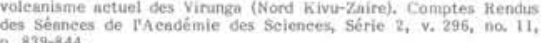
p. 839-844.

Kampunzu, A.B., Sebagenzi, M.N., Caron, J-P.H. and Vellutini, P-J.,
1982 . Comparaison petrochimigue entre les laves du champ Sud-Kivu (Bukaveu) et du Nord Kivu (Virungus), Znire. Annales de is

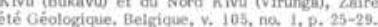

Kempunzu, A.B., Vellutini, P-J., Caron, J-P.H., Lubala, R.T., Kanika, Mi, and Rurnvegeri, B.T., 19.ssc. Le volennisime et l'évolution structuraie du Su Kivu (Zaire). Un modèle d'interprétation Centres de Recherehes Exploration. Produetion kIf-Aquitaine, v. 7,

Kunika, M., 1994. Etude pétrologique de la province voleanique de interprétntions géodynam. Pétrogrtaphie, minérnlogie, géochimie et Mniversité Lubumbasti, Zaire, 148p.
Uniter

Kanika, M., Kampunzu, A.B., Caron, J-P.H. and Vellutini, P-J.,

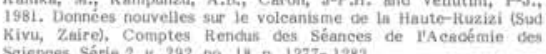
Sciences, Série 2, v. 292, no. 18, p. 1277-1282.

Lameyre, J., Black, R., Bonin, B. and Giret, A., 1983. The magmantic tions for a tectonic control of within-plate inaginatism triggered from above and associnted processes, Annales Société Geologique du Lameyre, J., Black, R., Bonin, B., and Giret, A., 1985. Dynamique lithosphérique et genese des magmas mantélligues. Compten Rendus
des séances de l'Aeadémie des seiences, Séric 2, v. 300, no, 1 ,
p. $21-26$.

Leger, J.M., 1985. Gćologie et évolution magmatique ou complexe plutonique d'Iskou (Air, Niger). Journal of African Earth Selences, Lippard, S.J. and Truekle, P.H., 1978. Spatial and temporal variertions in basalt geoehemistry in the N. Kenya rift. In: E.R. Neumann and 1.B. Ramberg (eds.), Petrology and geochenistry of continental systems with emphasis on the Permian Osio Rift, Series C, v. 36 , p. $123-131$.

Lubala, R.T., 1981. Etude géologique du massif du Biega (Kivu, tectonique. Thèse Doetorale, Université. Lubunbashi, Znire, 308p. Lubala, R.T., Kampunzu, A.B., Caron, J-P.H., Vellutini, P-J. and Reques, M., 1982. Sur la nature et la signification possible des
bassaltes de la Lugulu au Sud-Kivu (Zaire). Comptes Rendus des
Séanees de Thacadémie des Seiences, Série 2, v. 294, na. 5,
p. 325-328. Lubali, R.T., Kampunzu, A.B., Caron, A-P.H. and Vellutini, P-J.; Hieza (Rift du Kivu Znire) Annales de in Société Géologique de Belgique, v. 107, p. 125-134.

Marineili, G. and Varet, J., 1973. Strueture et évolution du Sud du "horst Danakil" (T.F.A., et Ethiopie), Comptes Rendus des Súnnes de I'Acadérnie des Seiences, v. 276, p. 1122 . Motir, P. 1983 . Perspectives on the Ethiopin
Bulletin Voleanologique, v. 46 , no. 1, p. $23-43$.

Pasteels, P., de Pacpe, P., Villeneuve, M. and Klerkx, J., 1985. Age of the volcanism of the southern Kivu area (Western Rift: Znire, Rwanda, Burundi). $13 \mathrm{th}$ Colloquium on Afriean Geology, St.
Andrews, Seotland. Abstracts in Oecasional Publication 1985/3, Centre International pour la For orintion et les Eehanges Géologiques,

Piecirillo, E.M., Justin-Visentin, E., Zanettin, B., Joron, J.L. and Treuil, M., 1979. Geodynamic evolution from plateau to rift, major platenu volcanics. Neues Jatirbuch fur Geologie und Paluontologie Abhandlungen, v. 158, no. 2, p. 139-179.

Poport, M., Kampunzu, A.B., Coulon, C., and Esquevin, J., 1982. ignifieation Nigerria: datations absolves caracteres magimatiques et signification
dans l'évolution du rift de la Béteoue. Travaux du Laboratoire des

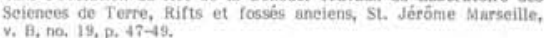
Sehubert, W., 1975. Petrographie und Geochimie des Südost-Escarpments von Aethiogian. In: Piliger, A, and Rósler, A. (eds.), Afar oepression of Ethiopin, Proceedings of an Internitional Symposium
held in Bad Benzzatier, Y.R. Germany, v. I. E. Schweizerbart'sche Verlagstuch- handlung (Nägele u. Oberniller), Stuttgart, p. 316-324. Sigvaldason, G.E., Steinthorsson, S., Oskirsson, N. and Imsland, P., 974. Compositional variation in recent leelandic tholeites and the

Sigvaidason, G.E., Steinthorsson, S., Oskarsson, N. and Inistand, P."
1976. The simultaneous production of tasalts, enriched and depleted

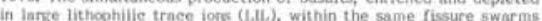
in loeland. Eulletin de la sociétét Géologique de France, Série? v. 18, no. 4, p. 863-867.

Stieltjes, L., Joron, J.L., Treuil, M. and Varet, J., 1976. Le rift d'Assal, segment de dorsale ćmergés: diseussion pétrologique et
géochimique. Bulletin Société Géologique de Prance, Série 7, v. 18. geochimique. Builietin
oo. 4, p. $851-862$.

Tazieff, H., Varet, J. and Barberi, $P_{\text {. . }}$ 1972, Voleanism in the afar depressiont its tectonic and magmatic significanee. Teetonophysies,

Tazieff, H., Varet, J., Barberi, F. and Giglia, G., 1972. Teetonic
simnificance of the Afar (or Daniaki depression, Nature, v. 235, significance of the $A$,
no. 5334, p. 144-147.

Treuil, N. and Vuret, J., 1973. Critères pótrologiques, péochimiques ot structuraux de lingenese et de la différenciation des magmas

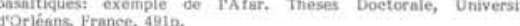
Vellutini, P.J., Kampunzu, A.B., Lubeila, R.T. and Caron, J.P-11.; 1982. Essal de synthese sur la efinimie des laves de l'épisoce récent di Aneiens, v. 19, p. 35-36, Travaux du Laboratoire des Sciences de Terre, Universite Marsellie III.

Watkins, K.T., 1981. The geochenistry of rhyolitie and tholeitic roeks from east of Lake Turkana, Northern Kenya. PhD. Thesis, the issp.

Zanettin, B., Gregnanin, A., Justin-Visentin, E.4 Mezzacasa, G. and
Piecirillo, E.M., 1974. Petrochemistry of the voleanie series of central Eastern Ethiopian plateau and relationships between tectonies and magmatology. Memorie de I'satituto geologieo della Zanettin, B., Justin-Visentin, E., Belleni, E., Pieeirillo, E.M. and Iith, F., 1983. Les voleanites du bassin du Nord-Turkana, Kenyaz Age, succession et evolution-structurale. Bulletin des Centres de
Recticeches Exploration. Production Eir-Aquitaine, p. 249-255. 